\title{
Spatial Arrangements on Growth and Yield of Cowpea (Vigna unguiculata L. Walp.) in Intercropping
}

\author{
Maduwanthi, A. K. M. R. B. and Karunarathna, B.* \\ Department of Crop Science, Faculty of Agriculture, Eastern University, Sri Lanka \\ *brinthak@esn.ac. $1 \mathrm{k}$
}

\begin{abstract}
This experiment was conducted at the Crop Farm of Eastern University, Sri Lanka to evaluate the effect of different spatial arrangements on growth and yield of cowpea (Vigna unguiculata L. Walp) under okra (Abelmoschus esculentus L.) cowpea intercropping in sandy regosol. The experiment was laid out in a Randomized Complete Block Design (RCBD) having monocropping and different intercropping patterns. The results revealed that there was a significant difference $(\mathrm{P}<0.05)$ among treatments for plant height, root length, leaf area, leaf area index, pod length, number of total and effective nodules per plant, dry weight of effective nodules and total pod yield of cowpea. However, seeds per pod was not significantly different $(\mathrm{P}>0.05)$ with different plating patterns. The study concluded that $60 \mathrm{~cm}$ between two rows with $150 \mathrm{~cm}$ between two pairs of rows of okra with three rows of cowpea in between paired rows would be the most suitable planting system to get maximum growth and yield of cowpea.
\end{abstract}

Keywords: Cowpea, Intercropping, Monocropping, Nodule, Yield

\section{Introduction}

Systems of food production should be increased for the continuous increasing population in the world while minimizing harmful effects to the environment. Most framers in both developing and developed countries are using various strategies with the sense of increasing the productivity and thus the income. Among these various strategies, smallholder farmers in the developing countries have tended to practice intercropping which increases the productivity per unit land area. Intercropping can be elaborated as a multiple cropping system where two or more crops species are planted simultaneously in a field during a growing season [Mousavi \& Eskandari, 2011].

Cowpea (Vigna unguiculata L. Walp.) mature grain contains 20 to $25 \%$ of protein, 1.3 to $1.5 \%$ lipid and 5.1 to $5.8 \%$ crude fiber [Basaran et al., 2011]. Cowpea can give good yield under adverse climatic conditions and under poor soil fertility. Land use and climate related-drivers are most important in determining agricultural productivity. Productivity of any crop can be influenced by various factors. Those factors may be either climatic or non-climatic. Low agricultural productivity can be attributed to non-climatic drivers such as limited use of external inputs like water and light, nutrient mining, soil erosion and deforestation and to climatic drivers such as precipitation, temperature and greenhouse gas emission [Epule et al., 2018]. The ability of the cowpea plant to fix atmospheric nitrogen is an important factor to maintain soil fertility and its deep roots improve soil structure while its tolerance to drought extends adaptation to drier areas considered marginal for most other crops [Singh et al., 1995].

Crop spacing can be defined as systematic distribution and planting of a material in a site with the intention of providing each individual by the same space and resources, like light, moisture and mineral nutrition [Milovanovic et al., 2011]. When practicing intercropping, spatial arrangement between base and intercropped plants are very much important in considering the productivity of the plants. When the inter-row spacing for the base crop is widened, it may provide adequate space and enable adequate sunlight reach to the intercropping plant and helps to produce more branches than under narrower inter-row spacing. Ultimately, it results in higher yield from intercropped plants. And spatial arrangement should be taken into consideration because it affects the shading of intercrop and causes poor sunlight penetration which ultimately causes poor production [Ocaya et al., 2001]. This study was done with the intention of evaluating the impact of different spatial arrangements on growth and yield of cowpea (Vigna unguiculata L. Walp.) under okra 
(Abelmoschus esculentus L.) cowpea intercropping.

\section{Methods}

The field experiment was conducted at the crop farm, Eastern University, Sri Lanka, to evaluate the impact of different spatial arrangements on growth and yield of cowpea (Vigna unguiculata L. Walp) under okra (Abelmoschus esculentus L.) intercropping. Crop farm of Eastern University belongs to the agro ecological region of low country dry zone in Sri Lanka. The soil of the experimental site is sandy regosol. The experiment was carried out using Randomized Complete Block Design (RCBD) with four replicates. Cowpea variety Waruni was used for the experiment and the size of each plot was $4 \mathrm{~m} \times 3 \mathrm{~m}$. Treatments were cowpea as a monocrop with the spacing of $30 \mathrm{~cm}$ $\times 15 \mathrm{~cm}$, alternative planting of okra and cowpea, $60 / 150 \mathrm{~cm}$ and $75 / 120 \mathrm{~cm}$ paired row planting of okra with two rows and three rows of cowpea in between paired rows. All the agronomic practices were done according to the recommendations of the Department of Agriculture, Sri Lanka. Growth parameters of cowpea were taken at two weeks intervals up to 60 days by the destructive sampling method. Plants were watered thoroughly and the root area with soil was uprooted by hand without damaging. Leaf area was measured by using the leaf area meter. Leaf Area Index (LAI) was calculated by the equation 1 .

$$
L A I=\frac{\text { Leaf area }}{\text { Canopy area }}
$$

Harvesting was started at 50 days after planting and continued at weekly intervals up to 70 days.

\section{Results and Discussion}

\section{Plant height}

There was a significant difference $(\mathrm{P}<0.05)$ in plant height at $6^{\text {th }}$ week after planting (WAP). However, the plant height of cowpea was not significantly different $(\mathrm{P}>0.05)$ among tested treatments at $2^{\text {nd }}$ and $4^{\text {th }}$ WAP as both okra and cowpea were trying to reach the vegetative growth. At $6^{\text {th }}$ WAP, the increase of plant height may be due to higher solar radiation caption by cowpea as okra plant height has predominantly suppressed. Tallest plants were noted in alternative planting $(49.90 \mathrm{~cm})$ and statistically the same height was noted in $75 / 120 \mathrm{~cm}$ paired row planting with three rows of cowpea. Zyada (2016) stated that cowpea plant height was higher in okra cowpea intercropping in 1:1 ratio, than sole cropping. Obedoni et al. (2005) stated that cowpea plant height was high in intercropping with low plant density of tomato, than sole cropping of cowpea. At $8^{\text {th }}$ WAP, there was no significant difference, because life cycle of cowpea ended up and most of the energy of the plant has expended for the yield.

\section{Root length}

There was no significant difference $(\mathrm{P}>0.05)$ between treatments at $2^{\text {nd }}$ week and $4^{\text {th }}$ WAP. Significant difference $(\mathrm{P}<0.01)$ was observed in $6^{\text {th }}$ and $8^{\text {th }}$ WAP. Alternative row planting showed the maximum root length $(19.84 \mathrm{~cm})$ while $75 / 120$ $\mathrm{cm}$ paired row planting of okra with two rows of cowpea $(11.38 \mathrm{~cm})$ showed the minimum mean values of root length. However, minimum value was not significantly different from same paired row planting with three rows of cowpea at $6^{\text {th }}$ WAP.

At $8^{\text {th }}$ WAP, root length in monocropping, $60 / 150 \mathrm{~cm}$ and $75 / 120 \mathrm{~cm}$ paired rows of okra with two and three rows of cowpea was not significantly different. But these significantly differed from alternative planting. This may be due to plant density of both okra and cowpea in alternative planting was less and this was less than monocropping also. So, under the ground level, cowpea roots grew well and freely with less disturbance, dense rooting, in searching water and nutrients. Banik et al. (2006) stated that, there is no significant difference in root length of chick-pea when intercropped with wheat.

\section{Number of leaves and branches per plant}

There was no significant difference $(\mathrm{P}>0.05)$ in number of leaves per plant with different planting patterns at $2^{\text {nd }}, 4^{\text {th }}$ and $8^{\text {th }}$ WAP. But there was a significant difference $(\mathrm{P}<0.05)$ in number of leaves with cropping system was observed at $6^{\text {th }}$ WAP. Highest number was observed in alternative rows (11) and lowest was observed in $75 / 120 \mathrm{~cm}$ paired row planting of okra with two rows (8). This may be due to the increased plant density in sole cropping of cowpea than intercropping systems. It may cause higher competition for space, light and nutrients. Zyada (2016) stated that the number of leaves per plant was higher in intercropping than sole cropping of cowpea. Madisa et al. (2015) also has stated that, higher plant densities cause more competition for space, light and nutrients. 
Table 1: Plant height $(\mathrm{cm})$ of cowpea at two weeks interval

\begin{tabular}{lcccc}
\hline Treatment & $2^{\text {nd }}$ WAP & $4^{\text {th }}$ WAP & $6^{\text {th }}$ WAP & $8^{\text {th }}$ WAP \\
\hline Monocropping & $13.05 \mp 0.46$ & $22.60 \mp 1.78$ & $32.51 \mp 4.39 \mathrm{c}$ & $34.34 \mp 2.50$ \\
Alternative row planting & $10.75 \mp 1.17$ & $23.60 \mp 0.90$ & $49.90 \mp 1.18 \mathrm{a}$ & $40.95 \mp 4.06$ \\
60/150 cm paired row planting & & & & \\
$\quad$ Two rows & $13.00 \mp 0.07$ & $20.81 \mp 1.11$ & $37.87 \mp 3.84 \mathrm{c}$ & $34.85 \mp 2.60$ \\
$\quad$ Three rows & $10.45 \mp 1.17$ & $22.27 \mp 0.49$ & $39.49 \mp 2.70 \mathrm{bc}$ & $35.89 \mp 4.06$ \\
$75 / 120 \mathrm{~cm}$ paired row planting & & & & \\
$\quad$ Two rows & $11.55 \mp 3.88$ & $22.35 \mp 0.51$ & $34.90 \mp 2.10 \mathrm{c}$ & $35.92 \mp 4.20$ \\
$\quad$ Three rows & $7.35 \mp 1.52$ & $17.16 \mp 2.42$ & $48.04 \mp 3.38 \mathrm{ba}$ & $40.83 \mp 1.67$ \\
F test & $\mathrm{ns}$ & $\mathrm{ns}$ & $*$ & $\mathrm{~ns}$
\end{tabular}

Value represents mean $\mp$ standard error of four replicates. $\mathrm{F}$ test: - *: $\mathrm{P}<0.05$; ns: not significant; Means followed by the same letter in each column are not significantly different according to the Duncans Multiple Range Test at $5 \%$ level.

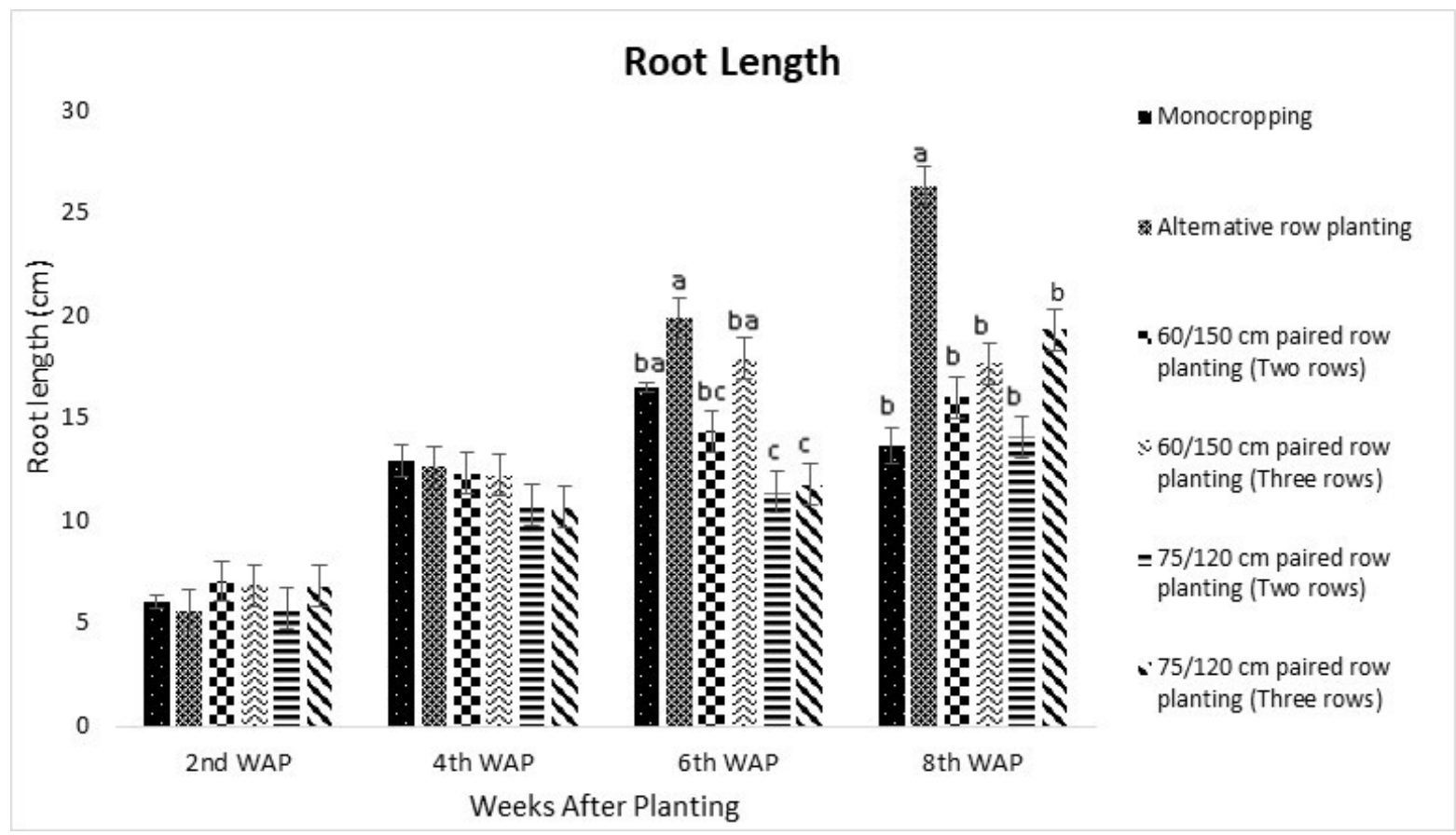

Figure 1: Root length $(\mathrm{cm})$ of cowpea at two weeks interval

Number of branches was not significantly different $(\mathrm{P}>0.05)$ with the planting pattern at $4^{\text {th }}$ WAP. There were significant differences $(\mathrm{P}<0.05)$ at $6^{\text {th }}$ and $8^{\text {th }}$ WAP. At $4^{\text {th }}$ WAP, there was no shading effect from okra on cowpea. But at $6^{\text {th }}$ and $8^{\text {th }}$ WAP, significant differences $(\mathrm{P}<0.05)$ were noted in branching, with different planting pattern may be due to shading effects. Kouyate et al. (2012) found that the shading effect of main crop influences the branching habit of cowpea. That may be the reason to have lower number of branches in sole cowpea at $6^{\text {th }} \mathrm{WAP}$, because it limits the light reaching inside the plant because of higher crop cover. Alternative row had maximum value due to the higher spacing than other intercropping treatments as well sole cropping. But at $8^{\text {th }}$ WAP, cowpea plants were at the latter part of the life cycle. So, no vegetative growth was observed. Therefore, in most of the treatments, the numbers of branches were not newly emerged. At $8^{\text {th }}$ WAP, the maximum numbers of branches were observed in alternative row. This may be due to the higher spacing. Zyada (2016) also reported that sole cropping of cowpea had the lowest number of branches per plant and the intercropping system of okra and cowpea in 2:2 ratio had the maximum number of branches per plant.

\section{Leaf area}

It was found that the leaf area was significantly different $(\mathrm{P}<0.01)$ between treatments at each 
Table 2: Number of leaves and branches per plant of cowpea at two weeks interval

\begin{tabular}{lccccccc}
\hline & $2^{\text {nd }}$ WAP & \multicolumn{2}{c}{$4^{\text {th }}$ WAP } & \multicolumn{2}{c}{$6^{\text {th }}$ WAP } & \multicolumn{2}{c}{$8^{\text {th }}$ WAP } \\
\cline { 2 - 8 } Treatment & Leaves & Leaves & Branches & Leaves & Branches & Leaves & Branches \\
\hline Monocropping & 4 & 7 & 3 & 10 & 4 & 8 & 4 \\
Alternative row planting & 5 & 9 & 5 & 11 & 8 & 11 & 7 \\
60/150 cm paired row plant- & & & & & & & \\
ing & 4 & 8 & 4 & 9 & 5 & 9 & 4 \\
$\quad$ Two rows & 5 & 8 & 6 & 10 & 6 & 10 & 6 \\
$\quad$ Three rows & & & & & & & \\
$75 / 120$ cm paired row plant- & & & & & & & 4 \\
ing & 4 & 8 & 4 & 8 & 3 & 7 & 4 \\
$\quad$ Two rows & 3 & 7 & 5 & 9 & 3 & 7 & 4 \\
$\quad$ Three rows & 0.132 & 0.512 & 0.271 & 0.009 & 0.000 & 0.156 & 0.017 \\
P value & 5.24 & 4.27 & 6.38 & 15.44 & 29.00 & 8.00 & 13.76 \\
Chi - square & & & & & & & \\
\hline
\end{tabular}

Table 3: Leaf area $\left(\mathrm{cm}^{2}\right)$ of cowpea at two weeks interval

\begin{tabular}{|c|c|c|c|c|}
\hline Treatment & $2^{\text {nd }} \mathrm{WAP}$ & $4^{t h} \mathrm{WAP}$ & $6^{t h} \mathrm{WAP}$ & $8^{t h}$ WAP \\
\hline Monocropping & $169.17 \mp 0.05 \mathrm{a}$ & $413.70 \mp 0.05 c$ & $1084.61 \mp 0.05 \mathrm{a}$ & $885.48 \mp 0.45 b$ \\
\hline Alternative row planting & $134.56 \mp 0.24 b$ & $369.70 \mp 0.24 \mathrm{~d}$ & $945.48 \mp 0.01 b$ & $830.37 \mp 2.24 b$ \\
\hline \multicolumn{5}{|c|}{$60 / 150 \mathrm{~cm}$ paired row planting } \\
\hline Two rows & $131.07 \mp 0.25 b$ & $490.78 \mp 0.01 b$ & $931.08 \mp 0.23 b$ & $777.10 \mp 1.24 \mathrm{cb}$ \\
\hline Three rows & $171.56 \mp 0.04 \mathrm{a}$ & $704.68 \mp 0.02 \mathrm{a}$ & $1209.71 \mp 1.65 \mathrm{a}$ & $1015.40 \mp 1.01 \mathrm{a}$ \\
\hline \multicolumn{5}{|c|}{$75 / 120 \mathrm{~cm}$ paired row planting } \\
\hline Two rows & $125.92 \mp 0.01 b$ & $395.35 \mp 0.11 \mathrm{dc}$ & $630.74 \mp 0.98 \mathrm{c}$ & $601.35 \mp 0.93 c$ \\
\hline Three rows & $129.74 \mp 0.09 b$ & $405.68 \mp 0.08 c$ & $828.84 \mp 0.27 \mathrm{~b}$ & $650.35 \mp 1.23 \mathrm{c}$ \\
\hline F test & $*$ & $* *$ & $*$ & $* *$ \\
\hline
\end{tabular}

Value represents mean $\mp$ standard error of four replicates. $\mathrm{F}$ test: - *: $\mathrm{P}<0.05 ;{ }^{* *}: \mathrm{P}<0.01$; Means followed by the same letter in each column are not significantly different according to the Duncans Multiple Range Test at $5 \%$ level.

Table 4: LAI of cowpea at two weeks interval

\begin{tabular}{lcccc}
\hline Treatment & $2^{\text {nd }}$ WAP & $4^{\text {th }}$ WAP & $6^{\text {th }}$ WAP & $8^{\text {th }}$ WAP \\
\hline Monocropping & $0.24 \mp 0.01$ & $0.62 \mp 0.01 \mathrm{~b}$ & $1.16 \mp 0.11 \mathrm{~b}$ & $1.04 \mp 0.01 \mathrm{~b}$ \\
Alternative row planting & $0.31 \mp 0.01$ & $0.50 \mp 0.01 \mathrm{~d}$ & $0.89 \mp 0.11 \mathrm{c}$ & $0.85 \mp 0.11 \mathrm{cb}$ \\
$60 / 150$ cm paired row planting & & & & \\
$\quad$ Two rows & $0.20 \mp 0.02$ & $0.53 \mp 0.11 \mathrm{~cd}$ & $0.68 \mp 0.01 \mathrm{dc}$ & $0.81 \mp 0.02 \mathrm{c}$ \\
$\quad$ Three rows & $0.31 \mp 0.01$ & $0.70 \mp 0.02 \mathrm{a}$ & $2.47 \mp 0.03 \mathrm{a}$ & $1.83 \mp 0.01 \mathrm{a}$ \\
$75 / 120 \mathrm{~cm}$ paired row planting & & & & \\
$\quad$ Two rows & $0.17 \mp 0.03$ & $0.32 \mp 0.11 \mathrm{e}$ & $0.58 \mp 0.02 \mathrm{dc}$ & $0.56 \mp 0.03 \mathrm{~b}$ \\
$\quad$ Three rows & $0.38 \mp 0.01$ & $0.59 \mp 0.01 \mathrm{cb}$ & $0.80 \mp 0.01 \mathrm{~d}$ & $0.71 \mp 0.14 \mathrm{~cd}$ \\
F test & $\mathrm{ns}$ & $*$ & $* *$ & $* *$ \\
\hline
\end{tabular}

Value represents mean $\mp$ standard error of four replicates. F test: - ${ }^{*}: \mathrm{P}<0.05 ; *$ : $\mathrm{P}<0.01$ ns: not significant Means followed by the same letter in each column are not significantly different according to the Duncans Multiple Range Test at $5 \%$ level.

sampling point (table 3). Observed differences may be due to levels of light interception [Wei, 2016]. Plants with different heights make more use of light when intercropped than monocropped [Herve et al., 2017]. The advantage of increasing leaf area in intercropped plants may be due to the height increase in different levels. At the $8^{\text {th }}$ WAP, mean values in all the treatments decreased because leafs started senescence. But, in $60 / 150 \mathrm{~cm}$ paired rows with three rows of cowpea had the highest value among them, as the senescence rate of that treatment was less because of the shading effect due 
Table 5: Leaf dry weight (g) of cowpea at two weeks interval

\begin{tabular}{lcccc}
\hline Treatment & $2^{\text {nd }}$ WAP & $4^{\text {th }}$ WAP & $6^{\text {th }}$ WAP & $8^{\text {th }}$ WAP \\
\hline Monocropping & $0.74 \mp 0.01 \mathrm{a}$ & $4.58 \mp 0.33 \mathrm{a}$ & $13.13 \mp 1.59 \mathrm{a}$ & $4.39 \mp 0.63$ \\
Alternative row planting & $0.62 \mp 0.03 \mathrm{cb}$ & $4.05 \mp 0.46 \mathrm{a}$ & $11.45 \mp 0.54 \mathrm{a}$ & $5.09 \mp 0.36$ \\
60/150 cm paired row planting & & & & \\
$\quad$ Two rows & $0.64 \mp 0.02 \mathrm{~b}$ & $3.27 \mp 0.12 \mathrm{bac}$ & $4.64 \mp 0.27 \mathrm{c}$ & $4.05 \mp 0.97$ \\
$\quad$ Three rows & $0.53 \mp 0.04 \mathrm{~cd}$ & $3.03 \mp 0.02 \mathrm{bc}$ & $7.76 \mp 0.95 \mathrm{~b}$ & $4.86 \mp 1.17$ \\
$75 / 120 \mathrm{~cm}$ paired row planting & & & & \\
$\quad$ Two rows & $0.44 \mp 0.00 \mathrm{e}$ & $3.55 \mp 0.21 \mathrm{ba}$ & $4.76 \mp 0.44 \mathrm{c}$ & $3.98 \mp 0.78$ \\
$\quad$ Three rows & $0.46 \mp 0.00 \mathrm{ed}$ & $2.61 \mp 0.24 \mathrm{c}$ & $4.09 \mp 0.29 \mathrm{c}$ & $3.52 \mp 0.43$ \\
F test & $*$ & $*$ & $*$ & $\mathrm{~ns}$ \\
\hline
\end{tabular}

Value represents mean $\mp$ standard error of four replicates. $\mathrm{F}$ test: - *: $\mathrm{P}<0.05$; ns: not significant; Means followed by the same letter in each column are not significantly different according to the Duncans Multiple Range Test at $5 \%$ level.

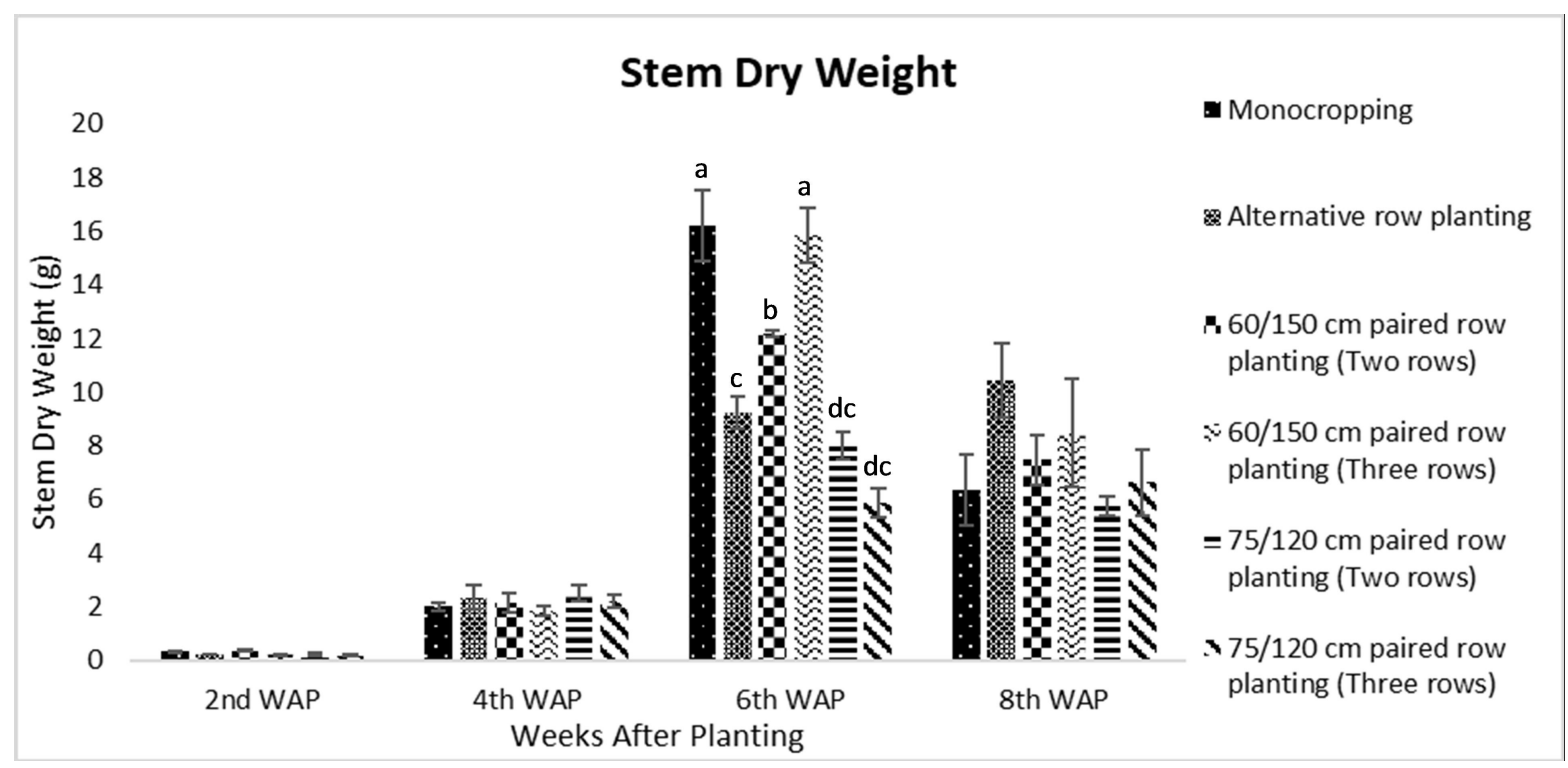

Figure 2: Stem dry weight (g) of cowpea at two weeks interval

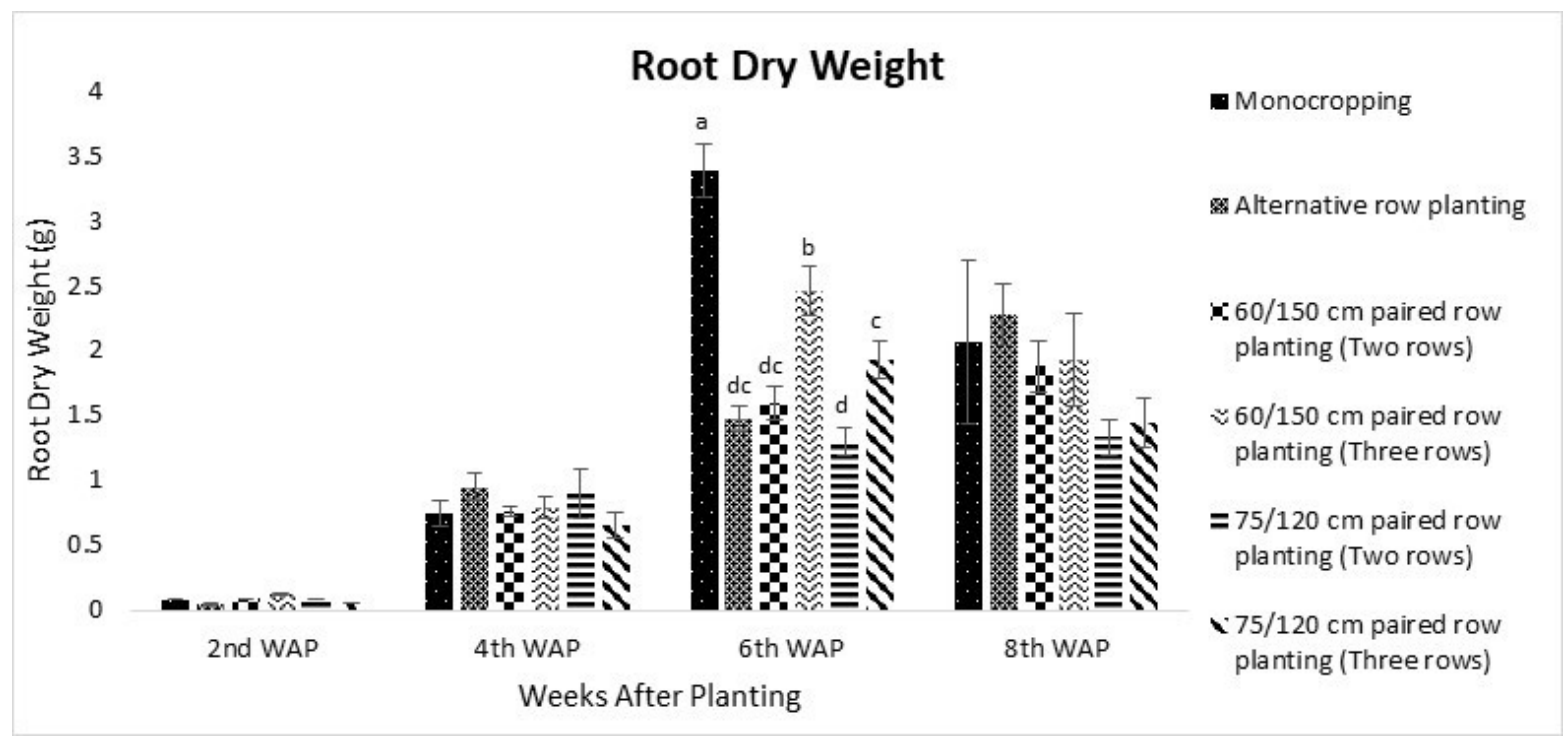

Figure 3: Root dry weight (g) of cowpea at two weeks interval 
to crowded nature with higher plant density. Herve et al. (2017) reported that leaf area of cowpea was increased when intercropped with maize than sole cropping of cowpea.

Table 6: Number of total nodules per plant at two weeks interval

\begin{tabular}{lccc}
\hline Treatment & $4^{\text {th }}$ & $6^{\text {th }}$ & $8^{\text {th }}$ \\
& WAP & WAP & WAP \\
\hline Monocropping & 40 & 85 & 194 \\
Alternative row planting & 33 & 90 & 200 \\
60/150 cm paired & & & \\
row planting & & & \\
$\quad$ Two rows & 35 & 61 & 116 \\
$\quad$ Three rows & 55 & 89 & 126 \\
75/120 cm paired & & & \\
row planting & & & \\
$\quad$ Two rows & 24 & 53 & 137 \\
$\quad$ Three rows & 25 & 69 & 171 \\
P value & 0.002 & 0.000 & 0.000 \\
Chi - square & 19.00 & 41.00 & 34.48 \\
\hline
\end{tabular}

Table 7: Number of effective nodules per plant at two weeks interval

\begin{tabular}{lccc}
\hline Treatment & $4^{\text {th }}$ & $6^{\text {th }}$ & $8^{\text {th }}$ \\
& WAP & WAP & WAP \\
\hline Monocropping & 32 & 93 & 121 \\
Alternative row planting & 22 & 78 & 118 \\
60/150 cm paired & & & \\
row planting & & & \\
$\quad$ Two rows & 28 & 54 & 87 \\
$\quad$ Three rows & 47 & 77 & 109 \\
75/120 cm paired & & & \\
row planting & & & \\
$\quad$ Two rows & 19 & 44 & 78 \\
$\quad$ Three rows & 20 & 54 & 99 \\
P value & 0.007 & 0.000 & 0.001 \\
Chi - square & 16.00 & 36.00 & 22.00 \\
\hline
\end{tabular}

\section{Leaf area index (LAI)}

Table 4 shows the LAI of the cowpea in different sampling points. According to that, there is no significant difference $(\mathrm{P}>0.05)$ in leaf area index (LAI) of cowpea at $2^{\text {nd }}$ WAP. However, LAI was significantly different $(\mathrm{P}<0.05)$ in $4^{\text {th }}, 6^{\text {th }}$, and $8^{\text {th }}$ WAP. The highest value of LAI was attained by a $60 / 150 \mathrm{~cm}$ paired row of okra with three rows of cowpea. At $4^{\text {th }}, 6^{\text {th }}$ and $8^{\text {th }} \mathrm{WAP}$, the lowest value was gained by $75 / 120 \mathrm{~cm}$ paired row of okra planting with two rows cowpea.
Higher LAI in $60 / 150 \mathrm{~cm}$ paired row of okra with three rows of cowpea may be due to the higher population of plants that produce a narrow canopy area due to limited spacing. But at $8^{\text {th }}$ WAP, cowpea started senescence. So, LAI may be reduced due to defoliation. Muoneke et al. (2012) found that LAI was higher in sole cropping of cowpea than intercropping with maize. Odedina et al. (2014) has reported that LAI of cowpea was high in intercropping treatments than sole cropping when cowpea intercropped with okra.

\section{Leaf dry weight}

It was found that there was a significant difference $(\mathrm{P}<0.05)$ in leaf dry weight at $2^{\text {nd }}, 4^{\text {th }}$ and $6^{\text {th }}$ WAP (table 5). Highest mean value of $0.74 \mathrm{~g}, 4.58 \mathrm{~g}$, and $13.13 \mathrm{~g}$ of leaf dry weight was obtained in monocropping at $2^{\text {nd }}, 4^{\text {th }}$ and $6^{\text {th }}$ WAP, respectively. Qasim et al. (2013) found that dry weight of leaves was high in sole cropping of pea than intercropped with cauliflower. At $6^{\text {th }}$ WAP the difference between monocropping and alternative planting was not significant. Due to the fact that leaf senescence and shedding was lower in sole cropping than intercropping, leaf dry weight was higher in sole cropping than intercropping systems. The reason for this is in intercropping systems, cowpea plants were shaded by okra plants.

\section{Stem dry weight}

Stem dry weight was not significantly different $(\mathrm{P}>0.05)$ between treatments at $2^{\text {nd }}, 4^{\text {th }}$ and $8^{\text {th }}$ WAP. But, a significant difference $(\mathrm{P}<0.01)$ was noted in stem dry weight at $6^{\text {th }}$ WAP (figure 2 ). The maximum mean value was observed in monocropping $(16.22 \mathrm{~g})$ which was par with a $60 / 150 \mathrm{~cm}$ paired row of okra with three rows of cowpea $(15.85 \mathrm{~g})$. Higher cowpea plant density in monocropping causes higher rate of $\mathrm{N}_{2}$ fixation and higher light interception causing higher accumulation of dry matter while giving higher stem weight. So, monocropping has a higher shoot dry weight. Mohamed (2007) has reported that intercropping cowpea and sorghum reduces the shoot dry weight of cowpea than sole cropping of cowpea. He also stated that this may be due to the shading effect from the other plant than cowpea.

\section{Dry weight of root}

It was found that, there is no significant difference $(\mathrm{P}>0.05)$ of root dry weight between 


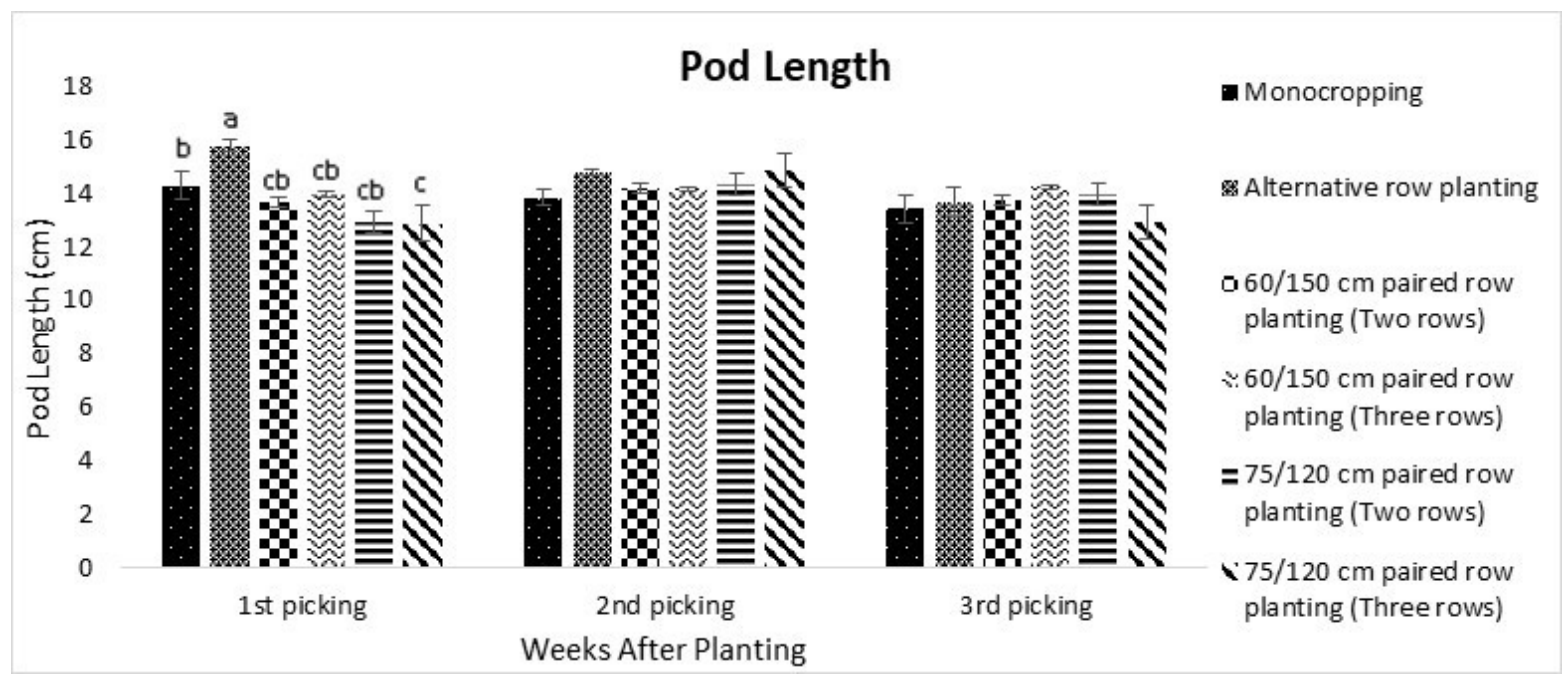

Figure 4: Pod length $(\mathrm{cm})$ of cowpea at each picking

Table 8: Dry weight of effective nodules (g) at two weeks interval

\begin{tabular}{lccc}
\hline Treatment & $4^{\text {th }}$ WAP & $6^{\text {th }}$ WAP & $8^{\text {th }}$ WAP \\
\hline Monocropping & $0.08 \mp 0.02 \mathrm{~b}$ & $0.12 \mp 0.06 \mathrm{c}$ & $0.50 \mp 0.02 \mathrm{~b}$ \\
Alternative row planting & $0.07 \mp 0.005 \mathrm{~b}$ & $0.34 \mp 0.04 \mathrm{~b}$ & $0.62 \mp 0.03 \mathrm{a}$ \\
$60 / 150 \mathrm{~cm}$ paired row plant- & & & \\
ing & & & \\
$\quad$ Two rows & $0.08 \mp 0.003 \mathrm{~b}$ & $0.11 \mp 0.05 \mathrm{c}$ & $0.44 \mp 0.03 \mathrm{~b}$ \\
$\quad$ Three rows & $0.18 \mp 0.06 \mathrm{a}$ & $0.59 \mp 0.04 \mathrm{a}$ & $0.66 \mp 0.02 \mathrm{a}$ \\
$75 / 120 \mathrm{~cm}$ paired row plant- & & & \\
ing & & & \\
$\quad$ Two rows & $0.02 \mp 0.006 \mathrm{~b}$ & $0.07 \mp 0.005 \mathrm{c}$ & $0.40 \mp 0.02 \mathrm{~b}$ \\
$\quad$ Three rows & $0.03 \mp 0.008 \mathrm{~b}$ & $0.32 \mp 0.08 \mathrm{~b}$ & $0.51 \mp 0.06 \mathrm{~b}$ \\
F test & $*$ & $*$ & $*$
\end{tabular}

Value represent mean $\mp$ standard error of four replicates. $\mathrm{F}$ test: - ${ }^{*}: \mathrm{P}<0.05$; Means followed by the same letter in each column are not significantly different according to the Duncans Multiple Range Test at $5 \%$ level.

treatments at $2^{\text {nd }}, 4^{\text {th }}$, and $8^{\text {th }}$ WAP. Significant differences $(\mathrm{P}<0.05)$ was observed only at $6^{\text {th }}$ WAP (figure 3). At $6^{\text {th }} \mathrm{WAP}$, the maximum value was gained by monocropping (3.39 g) while minimum of $1.30 \mathrm{~g}$ was recorded in $75 / 120 \mathrm{~cm}$ paired row of okra with two rows of cowpea. This may be due to the higher absorption and accumulation of nutrients due to less competition between species in monocropping. Mohamed (2007) stated that root dry weight was higher in sole cropping than intercropping with sorghum. Oliveira et al. (2017) stated that root dry weight of cowpea is not significantly affected, when cowpea intercropped with millet.

\section{Number of total nodules per plant}

It was observed that there was a significant difference $(\mathrm{P}<0.01)$ in total number of nodules per plant at each WAP (table 6). Njira et al. (2017) reported that number of nodules in pigeon pea was reduced when intercropped with cowpea. Further, Njira et al. (2017) noted that, this may be due to the competition for resources when intercropping legume - legume or legume - cereals. Number of nodules increased with increasing row spacing [Banik et al., 2006]. That may be the reason for increasing nodule number in the alternative row. Higher number of nodules may also be due to the facilitative interaction of intercropping [Banik et al., 2006].

\section{Number of effective nodules per plant}

Effective nodules are the sites of symbiotic nitrogen fixation. It was found that the number of effective nodules was significantly different $(\mathrm{P}<0.01)$ at each weekly interval at $5 \%$ significance 
Table 9: Days for $50 \%$ and $100 \%$ flowering in cowpea

\begin{tabular}{lcc}
\hline Treatment & $\begin{array}{c}\text { Days } \\
\text { for } 50 \% \\
\text { flowering }\end{array}$ & $\begin{array}{c}\text { Days } \\
\text { for } 100 \% \\
\text { flowering }\end{array}$ \\
\hline $\begin{array}{l}\text { Monocropping } \\
\text { Alternative row planting }\end{array}$ & 32 & 39 \\
60/150 cm paired & 36 & 44 \\
row planting & & \\
$\quad$ Two rows & 42 & 43 \\
$\quad$ Three rows & 38 & 44 \\
75/120 cm paired & & \\
row planting & & \\
$\quad$ Two rows & 43 & 48 \\
$\quad$ Three rows & 44 & 50 \\
P value & 0.003 & 0.075 \\
Chi - square & 18.00 & 10.00 \\
\hline
\end{tabular}

Table 10: Number of pods of cowpea per plant at each picking

\begin{tabular}{lccc}
\hline Treatment & $\begin{array}{c}1^{\text {st }} \\
\text { picking }\end{array}$ & $\begin{array}{c}2^{\text {nd }} \\
\text { picking }\end{array}$ & $\begin{array}{c}3^{\text {rd }} \\
\text { picking }\end{array}$ \\
\hline $\begin{array}{l}\text { Monocropping } \\
\text { Alternative row }\end{array}$ & 4 & 6 & 5 \\
planting & 5 & 7 & 6 \\
60/150 cm paired & & & \\
row planting & & & \\
$\quad$ Two rows & 3 & 5 & 3 \\
$\quad$ Three rows & 4 & 6 & 4 \\
75/120 cm paired & & & \\
row planting & & & \\
$\quad$ Two rows & 3 & 4 & 3 \\
$\quad$ Three rows & 2 & 5 & 2 \\
P value & 0.000 & 0.017 & 0.000 \\
Chi - square & 28.53 & 13.82 & 29.22 \\
\hline
\end{tabular}

level (table 7). At $4^{\text {th }}$ WAP, highest number of effective nodules was observed in $60 / 150 \mathrm{~cm}$ paired row of okra with three rows of cowpea. But at $6^{\text {th }}$ and $8^{\text {th }}$ WAP, the highest number of effective nodules was observed in monocropping. Higher number of effective nodules under intercropping system over sole cropping of legume shows that more atmospheric nitrogen fixation in the crop mixture [Banik et al., 2006]. With support to the present experiment, Kouyate et al., (2012) found that number of effective nodules of cowpea was high in sole cropping than the intercropping with millet. Number of effective nodules was high in haricot beans, when intercropped with maize in 1:1 ratio, than sole cropping of haricot bean [Abuna, 2015].

\section{Dry weight of effective nodules}

There were significant differences $(\mathrm{P}<0.05)$ in dry weight of nodules per plant recorded at $4^{\text {th }}$, $6^{\text {th }}$ and $8^{\text {th }}$ WAP (table 8). Highest dry weight was observed in $60 / 150 \mathrm{~cm}$ paired row of okra with three row cowpea at each week interval. Minimum weight was observed in $75 / 120 \mathrm{~cm}$ paired row of okra with two rows cowpea. This may be due to that when plant density increased, amount of atmospheric $\mathrm{N}_{2}$ may limit and it has a partitioning between all the plants and sole portion per plant will be low. But when plant density decreased, amount of atmospheric $\mathrm{N}_{2}$ may not limit for a small portion as such. And also, the microbial population will be high in low plant density. Kouyate et al. (2012) also cited that, increase in dry weight of nodules could be attributed with the different plant densities. Intercropping treatments with lower plant densities showed the highest dry weight of nodules in mungbean when intercropped with sugarcane [Singh et al., 2014]. Dry weight of nodules was high in sole cropping than intercropping, when cowpea intercropped with maize [Muoneke et al., 2012]. Dry weight of nodules was high when cowpea intercropped with millet in 1:2 ratio of cowpea: millet than sole cropping [Kouyate et al., 2012].

\section{Days to $50 \%$ and $100 \%$ flowering}

There was a significant difference $(\mathrm{P}<0.05)$ between treatments on days to $50 \%$ flowering. However, the effect of treatment on days to $100 \%$ flowering was not significant (table 9). Monocropping showed early $50 \%$ flowering at 32 days. Varying degrees of shading of cowpea by taller plants in intercropping combination, especially at later stages of growth could be responsible for the differences in days to $50 \%$ flowering in cowpea [Obedoni, 2005]. Ronald (2014) investigated that $50 \%$ flowering increased with the increase in plant density. This may be the reason for the shortening of time duration for $50 \%$ flowering in sole cropping of cowpea as the row spacing was reduced and number of plants was increased. Muoneke et al. (2007) reported that 50\% flowering of soybean was not different whether it is grown in sole or intercropped with maize. 
Table 11: Weight per pod (g) of cowpea at each picking

\begin{tabular}{lccc}
\hline Treatment & $1^{\text {st }}$ picking & $2^{\text {nd }}$ picking & $3^{\text {rd }}$ picking \\
\hline Monocropping & $1.50 \mp 0.04 \mathrm{~b}$ & $1.44 \mp 0.09 \mathrm{~b}$ & $1.58 \mp 0.08$ \\
Alternative row planting & $1.53 \mp 0.08 \mathrm{~b}$ & $1.71 \mp 0.07 \mathrm{ba}$ & $1.50 \mp 0.09$ \\
$60 / 150 \mathrm{~cm}$ paired row plant- & & & \\
ing & & & \\
$\quad$ Two rows & $1.51 \mp 0.08 \mathrm{~b}$ & $1.59 \mp 0.06 \mathrm{~b}$ & $1.53 \mp 0.05$ \\
$\quad$ Three rows & $1.51 \mp 0.02 \mathrm{~b}$ & $1.57 \mp 0.14 \mathrm{~b}$ & $1.53 \mp 0.06$ \\
$75 / 120 \mathrm{~cm}$ paired row plant- & & & \\
ing & & & \\
$\quad$ Two rows & $1.42 \mp 0.03 \mathrm{~b}$ & $1.79 \mp 0.25 \mathrm{ba}$ & $1.49 \mp 0.07$ \\
$\quad$ Three rows & $1.72 \mp 0.07 \mathrm{a}$ & $2.03 \mp 0.09 \mathrm{a}$ & $1.62 \mp 0.06$ \\
F test & $*$ & $*$ & $\mathrm{~ns}$ \\
\hline
\end{tabular}

Value represent mean $\mp$ standard error of four replicates. $\mathrm{F}$ test: - *: $\mathrm{P}<0.05$; ns: not significant; Means followed by the same letter in each column are not significantly different according to the Duncans Multiple Range Test at $5 \%$ level.

Table 12: Number of seeds of cowpea per pod at each picking

\begin{tabular}{lccc}
\hline Treatment & $\begin{array}{c}1^{\text {st }} \\
\text { picking }\end{array}$ & $\begin{array}{c}2^{\text {nd }} \\
\text { picking }\end{array}$ & $\begin{array}{c}3^{\text {rd }} \\
\text { picking }\end{array}$ \\
\hline $\begin{array}{l}\text { Monocropping } \\
\text { Alternative row }\end{array}$ & 10 & 10 & 12 \\
planting & 13 & 13 & 14 \\
60/150 cm paired & & & \\
row planting & & & \\
$\quad$ Two rows & 11 & 10 & 10 \\
$\quad$ Three rows & 12 & 11 & 11 \\
$\begin{array}{l}\text { 75/120 cm paired } \\
\text { row planting }\end{array}$ & & & \\
$\quad$ Two rows & 10 & 10 & 10 \\
$\quad$ Three rows & 10 & 10 & 10 \\
P value & 0.634 & 0.849 & 0.156 \\
Chi - square & 3.43 & 2.00 & 8.00 \\
\hline
\end{tabular}

\section{Number of pods per plant}

There was a significant effect $(\mathrm{P}<0.05)$ of cropping system on number of pods per plant of cowpea (table 10). Ronald (2014) found that when plant density is high, those plants produce a fewer number of pods per plant. That may be the reason to produce a higher number of pods by alternative row, which was with wider row arrangement. Obedoni et al. (2005) stated that, number of cowpea pods were high in intercropped cowpea with tomato, than sole cowpea cultivation. At the $3^{\text {rd }}$ picking, the number pods per plant has reduced to a greater extent, because cowpea plants started senescence. In contrast, Alhassan et al. (2012) stated that the number of pods per plant was higher in sole cropping than intercropping with Bambara groundnut.

\section{Pod length}

Figure 4 show the average pod length of cowpea at each picking. According to that, the pod length was significantly different $(\mathrm{P}<0.05)$ at $1^{\text {st }}$ picking. But there were no significant differences $(\mathrm{P}>0.05)$ were recorded at $2^{\text {nd }}$ and $3^{r d}$ picking. At $1^{\text {st }}$ picking, the highest pod length of cowpea was observed in an alternative row $(15.79 \mathrm{~cm})$ and lowest was observed in $75 / 120 \mathrm{~cm}$ paired row of okra with three rows of cowpea $(12.89 \mathrm{~cm})$. Monocropping was not significantly different with $60 / 150 \mathrm{~cm}$ paired rows of okra with two and three rows of cowpea and 75/120 paired rows of okra with three rows of cowpea. The increase in pod length of cowpea in alternative row may be due to more accumulation of dry matter with the increase spacing and light penetration with reduction of plant density compared to sole cropping. Least populated plots may have produced broader leaves which translated into higher pod length. Reducing plant density can increase the width of leaves [Muoneke et al., 2012]. With synchronization to the results, Muoneke et al. (2012) stated that higher lengths of cowpea pods can be obtained in cropping systems with least plant population.

\section{Weight per pod of cowpea}

The weight per pod was significantly different $(\mathrm{P}<0.05)$ in $1^{\text {st }}$ picking and $2^{\text {nd }}$ picking. There was no significant variation in the weight per pod at $3^{r d}$ picking (table 11). At $1^{\text {st }}$ and $2^{\text {nd }}$ picking, the maximum value per pod of cowpea was obtained 
Table 13: Total pod yield (t/ha) of cowpea at each picking

\begin{tabular}{|c|c|c|c|}
\hline Treatment & $1^{\text {st }}$ picking & $2^{\text {nd }}$ picking & $3^{r d}$ picking \\
\hline Monocropping & $1.59 \mp 0.18 \mathrm{a}$ & $2.99 \mp 0.48 \mathrm{a}$ & $2.03 \mp 0.20 \mathrm{a}$ \\
\hline $\begin{array}{l}\text { Alternative row planting } \\
60 / 150 \mathrm{~cm} \text { paired row } \\
\text { planting }\end{array}$ & $1.55 \mp 0.66 \mathrm{a}$ & $2.22 \mp 0.29 \mathrm{ba}$ & $1.87 \mp 0.19 \mathrm{ba}$ \\
\hline Two rows & $1.01 \mp 0.19 b$ & $1.77 \mp 0.12 b$ & $1.00 \mp 0.22 \mathrm{dc}$ \\
\hline Three rows & $1.26 \mp 0.15 \mathrm{ba}$ & $2.26 \mp 0.39 \mathrm{ba}$ & $1.39 \mp 0.06 \mathrm{bc}$ \\
\hline $\begin{array}{l}75 / 120 \mathrm{~cm} \text { paired row } \\
\text { planting }\end{array}$ & & & \\
\hline Two rows & $0.88 \mp 0.04$ & $1.79 \mp 0.28 b$ & $1.03 \mp 0.13 \mathrm{dc}$ \\
\hline Three rows & $0.86 \mp 0.14 \mathrm{~b}$ & $2.19 \mp 0.24 \mathrm{ba}$ & $0.83 \mp 0.09 \mathrm{~d}$ \\
\hline F test & $*$ & $\mathrm{Ns}$ & $* *$ \\
\hline
\end{tabular}

Value represent mean $\mp$ standard error of four replicates. $\mathrm{F}$ test: - $^{*}: \mathrm{P}<0.05$; $^{* *}: \mathrm{P}<0.01$ ns: not significant; Means followed by the same letter in each column are not significantly different according to the Duncans Multiple Range Test at $5 \%$ level.

Table 14: Sun dried weight of 100 seeds $(\mathrm{g})$ of cowpea at each picking

\begin{tabular}{lccc}
\hline Treatment & $1^{\text {st }}$ picking & $2^{\text {nd }}$ picking & $3^{\text {rd }}$ picking \\
\hline Monocropping & $9.54 \mp 0.42 \mathrm{~b}$ & $12.93 \mp 0.78 \mathrm{~d}$ & $11.49 \mp 0.49 \mathrm{c}$ \\
$\begin{array}{l}\text { Alternative row planting } \\
60 / 150 \mathrm{~cm} \text { paired row }\end{array}$ & & & \\
planting & & & \\
$\quad$ Two rows & $10.88 \mp 1.02 \mathrm{~b}$ & $14.77 \mp 0.01 \mathrm{bc}$ & $13.33 \mp 0.57 \mathrm{~b}$ \\
$\quad \begin{array}{l}\text { Three rows } \\
75 / 120 \mathrm{~cm} \text { paired row }\end{array}$ & $10.32 \mp 0.53 \mathrm{~b}$ & $13.96 \mp 0.11 \mathrm{dc}$ & $12.52 \mp 0.2 \mathrm{cb}$ \\
planting & & & \\
$\quad$ Two rows & $12.54 \mp 0.13 \mathrm{a}$ & $15.68 \mp 0.28 \mathrm{ba}$ & $14.49 \mp 0.57 \mathrm{a}$ \\
$\quad$ Three rows & $12.86 \mp 0.24 \mathrm{a}$ & $16.06 \mp 0.66 \mathrm{a}$ & $14.81 \mp 0.31 \mathrm{a}$ \\
F test & $* *$ & $* *$ & $*$ \\
\hline
\end{tabular}

Value represents mean $\mp$ standard error of four replicates. $\mathrm{F}$ test: - *: $\mathrm{P}<0.05 ;{ }^{* *}: \mathrm{P}<0.01$; Means followed by the same letter in each column are not significantly different according to the Duncans Multiple Range Test at $5 \%$ level.

in $75 / 120 \mathrm{~cm}$ paired row of okra with three row of cowpea. This may be due to more accumulation of dry matter in the available limited number of pods causing higher dry weight of 100 seeds.

\section{Number of seeds per pod}

There was no significant influence $(\mathrm{P}>0.05)$ of planting system on number of seeds per pod (table 12). Legwaila et al. (2012) stated that there is no significant difference $(\mathrm{P}>0.05)$ in the number of seeds per pod in cowpea when intercropped with maize. Ronald (2014) reported that there was a significant difference in number of seeds per pod under 1 row Maize: 1 row cowpea intercropping pattern and sole cropping systems. Abuna (2015) found results that were supportive to the results of the present experiment that there was no significant difference in the number of seeds per pod of haricot bean, when intercropped with maize.

\section{Total pod yield/picking}

It was resulted that, there was significant variation among treatments in $1^{\text {st }}$ picking $(\mathrm{P}<0.05)$ and $3^{\text {rd }}$ picking $(\mathrm{P}<0.01)$. But there was no significant difference $(\mathrm{P}>0.05)$ in $2^{\text {nd }}$ picking was recorded is shown in table 13 . At $1^{\text {st }}$ picking, the highest mean value was observed in monocropping $(1.59 \mathrm{t} / \mathrm{ha})$ and the least mean value was observed in $75 / 120 \mathrm{~cm}$ paired row of okra with three rows cowpea $(0.86 \mathrm{t} / \mathrm{ha})$. At the $3^{\text {rd }}$ picking, the highest mean value of $2.03 \mathrm{t} /$ ha was observed in the sole cropping of cowpea followed by alternative row $(1.87 \mathrm{t} / \mathrm{ha})$. Least value was observed in $75 / 120$ $\mathrm{cm}$ paired row of okra with three row cowpea (0.83t/ha). Zyada (2016) cited that yield of cowpea decreased with the intercropping treatments with okra and highest was given by sole cropping. This may be due to the reduction of competition by two 
different species. Zyada (2016) has also confirmed the same idea. Quite similar results were obtained by Choudhuri (2011) confirming the results of the present study. He cited as sole cowpea cultivation gave the maximum yield and minimum reduction of yield of cowpea was observed in okra and cowpea intercropping system in between okra planted in 50 $\times 50 \mathrm{~cm}$ compared to other treatments. This may be due to the symbiotic relationship between okra and cowpea.

\section{Dried weight of 100 seeds}

Table 14 shows the weight of 100 seeds after sun dried (10/hours/days). It was significantly different $(\mathrm{P}<0.05)$ from treatments at each picking. The maximum value was observed in a $75 / 120$ $\mathrm{cm}$ paired row of okra with three row cowpea, without any significant difference with the same paired row with two row cowpea. Minimum value was observed in monocropping at each picking. This may be due to the quiet higher pod yield in monocropping. So, the maximum amount of photosynthates accumulate in the available seeds. Highest value for 100 seed weight was obtained by $75 / 120 \mathrm{~cm}$ paired row of okra with three rows of cowpea. This was because, in $75 / 120 \mathrm{~cm}$ paired row of okra with three rows of cowpea there was the minimum number of pods (table 10) and minimum number of seeds per pod (table 12). So, the available photosynthates are distributed among the available a few numbers of seeds. Alternative row and $60 / 150 \mathrm{~cm}$ paired row of okra with two and three rows cowpea were not significantly different. Odedina et al. (2014) also reported that 100 seed weight of cowpea is higher in intercropping systems of okra and cowpea than mono-cropping of cowpea. And, their findings were supportive to the above results as the 100 seed weight was high in less pod weight. Similarly, Legwaila et al. (2012) stated that 100 seed weight of cowpea was not significantly affected under the intercropping system of maize and cowpea.

\section{Conclusion}

The present study revealed that plant height, root length, number of leaves and branches and pod length were superior in alternative row. Leaf area, leaf area index, dry weight of effective nodules was high in 60/150 cm paired row of okra with three rows of cowpea. Number of effective nodules was higher in monocropping at $6^{\text {th }}$ and $8^{\text {th }}$ WAP. $50 \%$ flowering showed significant difference $(\mathrm{P}<0.05)$ while giving superior in monocropping. Seeds per pod were not significantly different $(\mathrm{P}>0.05)$ between plating patterns. Monocropping showed higher pod yield, followed by alternative row and $60 / 150 \mathrm{~cm}$ paired row of okra with three row cowpea. Weight per pod and sun dried weight of 100 seeds was higher in $75 / 120 \mathrm{~cm}$ paired rows of okra with three row cowpea. According to this study, when considering the growth and yield, it can be suggested that among the all tested treatments, $60 / 150 \mathrm{~cm}$ paired row planting of okra with three rows of cowpea in between paired rows would be the most suitable planting system for sandy regosol when compared with other tested treatments.

\section{References}

Abuna, W.G. (2015). A study of the effect of intercrop row arrangement on maize and haricot bean yield on residual soil. Journal of Agroforestry and Silviculture, v.24, pp.127-134.

Alhassan, G.A., Kalu, B, A. \& Egbe, O.M. (2012). Influence of planting densities on the performance of intercropped bambara groundnut with cowpea in Makurdi, Benue state, Nigeria. International Journal of Development and Sustainability, v.1 (3), pp.1-20.

Banik, P., Midya, A., Sarkar, B.K. \& Ghose, S.S. (2006). Wheat and chickpea intercropping systems in an additive series experiment: advantages and weed smothering. European Journal of Agronomy, v. 24, pp.325-332. DOI: 10.1016/j.eja.2005.10.010

Basaran, U ., Ayan, I., Acar, Z., Mut, H. \& Asci, O.O. (2011). Seed yield and agronomic parameters of cowpea (Vigna unguiculata L.) genotypes grown in the Black Sea region of Turkey. African Journal of Biotechnology, v. 10(62), pp.13461-13464. DOI: 10.5897/ajb11.2489

Choudhuri, P. (2011). Growth, yield, quality and economic impacts of intercropping in vegetable and spice crops. Ph. D thesis, West Bengal (IN): Uttar Banga Kirishi Viswavidyalaya.

Epule, T.E., Ford, J.D., Lwasa, S., Nabaasa, B. \& Buyinza, A. (2018). The determinants of crop yields in Uganda: what is the role of climatic and non-climatic factors?. Agriculture 
and Food Security, v. 7(10), pp.1-17. DOI: 10.1186/s40066-018-0159-3

Herve, K.S., Falengue, C.L., Yao, K.B., Yaya, T., Juliette, D.K. \& Mongomake, K. (2017). Effect of row spatial arrangements on agro morphological responses of maize (Zea mays L.) and cowpea (Vigna unguiculata (L.) Walp) in an intercropping system in Southern Cote d'Ivoire. African Journal of Agriculture, v.12 (34), pp.2633-2641. DOI: 10.5897/ajar2017.12509

Kouyate, Z., Krasova-Wade, T., Yattara, I.I. \& Neyra, M. (2012). Effects of cropping systems and cowpea variety on symbiotic potential and yields of cowpea (Vigna unguiculata L.Walp) and pearl millet (Pennisetum glaucum L.) in the Sudano-Sahelian zone of Mali. International Journal of Agronomy, v. 1, pp.1-8. DOI: $10.1155 / 2012 / 761391$

Legwaila, G.M., Marokane, T.K. \& Mojeremane, W. (2012). Effect of intercropping on the performance of maize and cowpeas in Botswana. International Journal of Agriculture and Forestry, v.2 (6), pp.307-310. DOI: $10.5923 /$ j.ijaf.20120206.07

Madisa, M.E., Mathowa, T., Mpofu, C. \& Oganne, T.A. (2015). Effects of plant spacing on the growth, yield and yield components of okra (Abelmoschus esculentus L.) in Botswana. American Journal of Experimental Agriculture, v. 6 (1), pp.7-14. DOI: 10.9734/ajea/2015/14199

Milovanovic, J., Babovic, N., Dordevic, A., Spasic, S., Marisova, E., Koncekova, L., Kotrla, M. \& Tothova, M. (2011). External and internal factors influencing the growth and biomass production of short rotation woods genus Salix and perennial grass Miscanthus. Jurekova Z, Drazic G, (Eds). Belgrade: Faculty of Applied Ecology. Jurekova Z, Drazic G, editors. 2000

Mohamed, M.F., Dokashi, M.H., Mousa, M.A.A. \& Elnobi, E.F.E. (2007). Yield of crops in within-row intercropped okra-cowpea or okra-cucumber. International Journal of vegetable sciences, v.13 (2), pp.33-48. DOI: 10.1300/j512v13n02_04

Mousavi, S.R. \& Eskandari, H. (2011). A general overview on intercropping and its advantages in sustainable agriculture. Journal of Applied
Environment and Biological Sciences, v.1 (11), pp.482-486.

Muoneke, C.O., Ogwuche, M.A.O. \& Kalu, B.A. (2007). Effect of maize planting density on the performance of maize/soybean intercropping system in a guinea savannah agro ecosystem. African Journal of Agricultural Research, v.2 (12), pp.667-677.

Muoneke, C.O., Ndukwe, O.O., Umana, P.E., Okpara, D.A. \& Asawalam, D.O. (2012). Productivity of vegetable cowpea (Vigna unguiculata (L.) Walp) and maize (Zea mays L.) intercropping system as influenced by component density in a humid tropical zone of south-eastern Nigeria. International Journal of Agriculture and Rural Development, v.15 (1), pp.835-847.

Njira, K.O.W., Semu, E., Mrema, J.P. \& Nalivata, P.C. (2017). Biological nitrogen fixation by pigeon pea and cowpea in the doubled-up and other cropping systems on the Luvisols of Central Malawi. African Journal of Agricultural Research, v.12 (15), pp.1341-1352. DOI: 10.5897/ajar2017.12167

Obedoni, B.O., Menash, J.K. \& Isesele, S.O. (2005). Effects of intercropping cowpea (Vigna unguiculata (L) Walp) and tomato (Lycopersicon esculentum Mill) on their growth, yield and monetary returns. Indian Journal of Agricultural Research, v.39 (4), pp.286-290.

Ocaya, C.P., Adipala, E. \& Osiru, D.S.O. (2001). Effect of spatial arrangement on growth and yield of cowpea in a cowpea-maize intercrop. Tropicultural, v.19 (4), pp.184-187.

Odedina, J.N., Fabunmi, T.O., Adigbo, S.O., Odedina, S.A. \& Kolawole, R.O. (2014). Evaluation of cowpea varieties (Vigna unguiculata L.Walp) for intercropping with okra (Abelmoschus esculentus L. Monech). American Journal of Research Community, v.2 (2), pp.91108.

Oliveira, L.B.D., Barros, R.L.N., Magalhaes, W.B.D., Medici, L.O. \& Pimentel, C. (2017). Cowpea growth and yield in sole crop and intercropped with millet. Rev Caatinga. v.30 (1), pp.53-58. DOI: 10.1590/1983- 
21252017v30n106rc

Qasim, S.A., Anjum, M.A., Hussain, S. \& Ahmad, S. (2013). Effect of pea intercropping on biological efficiencies and economics of some non - legume winter vegetables. Pakistan Journal of Agricultural Science, v.50 (3), pp.399-406.

Ronald, K. (2014). Influence of plant density and intercropping on the performance of elite cowpea varieties in eastern Uganda, (M.Sc. thesis, Kampala (UG): Makerere University.

Singh, B.I., Mai-Kodomi, Y. \& Terao, T. (1995). A simple screening method for drought tolerance in cowpea. Agronomy Abstract. American Society of Agronomy, Madison, Wisconsin, USA, pp.71.
Singh, P., Chouhan, V., Tiwari, B.K., Chauhan, S.S., Simon, S., Bilal, S. \& Abidi, A. (2014). An overview on okra (Abelmoschus esculentus) and its importance as a nutritive vegetable in the world. International Journal of Pharmaceutical Biology and Science, v.4 (2), pp.227-233.

Wei, H.E. (2016). Field evaluation of maize legume intercropping system in the mid hills of Nepal. M.Sc. thesis, Wageningen (NL): Wageningen University.

Zyada, H.G. (2016). Growth, Yield and its Components, Chemical constituents, correlation coefficient and competition indices of okra and cowpea as influenced by different intercropping systems. Middle East Journal of Agricultural Research, v.5 (4), pp.726-738. 